\title{
負血ラットにみられる鉄吸収の㐫進について
}

\author{
吉野芳夫*, 平松芳子*, 柳下 晃*, 寺戸国晊** \\ * 日本医科大学栄養学教室 \\ **エーザイ株式会社
}

\section{The Acceleration of Iron Absorption in Response to Iron Deficient Anemia of Rats}

\author{
Yoshio Yoshino*, Yoshiko Hiramatsu*, Akira Yagishita*, Kuniaki Terato** \\ * Department of Nutrition, Nippon Medical School, Bunkyo-ku, Tokyo \\ **Eisai Research Laboratories, Bunkyo-ku, Tokyo
}

J. Japan Soc. Food and Nutr. 24 (4) 206 210 (1971)

Iron deficient rats (from Donryu strain) were prepared by feeding of iron poor diet for two months. The rats fed on the iron poor diet+deionized water became within this period: body weight $526 \pm 4.5 \rightarrow$ $201.2 \pm 29.3 \mathrm{~g}$, hemoglobin $11.6 \pm 1.2 \rightarrow 9.7 \pm 1.5 \mathrm{~g} / \mathrm{d} l$ and liver nonhemin iron $11.6 \sim 15.1 \mu \mathrm{g} / \mathrm{g}$. The control rats fed on the iron poor diet+iron supplemented drinking water grew as follows: body weight $52.1 \pm$ $4.7 \rightarrow 228.4 \pm 32 . \mathrm{cg}$, hemoglobin $11.6 \pm 1.2 \rightarrow 15.4 \pm 1.4 \mathrm{~g} / \mathrm{d} l$ and liver nonhemin iron $112.6 \mu \mathrm{g} / \mathrm{g}$.

The rate of iron absorption was assayed after the administration of $\mathrm{FeSO}_{4}$ which was given in ten doses of $0.3 \mathrm{mg} \mathrm{Fe}$ per os. Intestinal absorption of ${ }^{59} \mathrm{Fe}$ given with the first dose of iron was $30.8 \sim$ 43. $4 \%$ in the iron deficient rats and that of control animals was $7.8 \%$. Hemoglobin value of the iron deficient rats recovered to $12.5 \sim 14.6 \mathrm{~g} / \mathrm{d} l$, but the value of the control showed few change. Accumulation of liver nonhemin iron increased in iron deficient rats. From these results the following equations were calculated between hemoglobin values $(\mathrm{xg} / \mathrm{d} l)$ and percentage of iron absorption $(\mathrm{y}): \mathrm{y}=10895 \mathrm{x}^{-2.578}$, and between hemoglobin values $(\mathrm{xg} / \mathrm{d} l)$ and liver nonhemin iron $(\mathrm{y} \mu \mathrm{g}): \mathrm{y}=2.032 \times 10^{-4} \mathrm{x}^{5.413}$.

(Received February 4, 1971)

坌血状態に括いてては腸管の鉄吸収はむしろ充進すると (われている(1) こ)。これは生体の要求に対応してみられ る自律的な調節現象であると考兄られる。鉄欠乏性貧血 においては血液へモグロビン值（以下 $\mathrm{Hb}$ 值と略）の低 下と蔵器非へミン鉄の減少がみられるので, それらと鉄 吸収との相関をドンリューラットを用いて観察した。 ${ }^{9} \mathrm{FeSO}$ 、あるいは硫酸第一鉄を連続経口負荷した場合の 血液 $\mathrm{Hb}$ 值拉上び肝臓非へミン鉄への ${ }^{59} \mathrm{Fe}$ の取り込み と鉄欠乏の恢復について㭘討した。

\section{実 験 万 法}

雄ドンリューラット（体重40～60 g ）160匹を日本ラ ット社より一括購入し, 隇菌オガクズ入りのプラスチッ ク飼有箱で 2 力月間飼育した。ラットは鉄欠之食群 1.00 匹と対照群60匹の 2 群に区分し, 前者には除鉄飼料（オ
リエンタル醉母製，表 1) および飲料水に脱イオン水を ad libitum に与えた。後者には同じく除鉄飼料と飲料 水に硫酸第一鉄 $50 \mathrm{mg} \mathrm{Fe} / l$ （脱イオン水に溶解）溶液を 与えた。

上記の鉄欠乏ラット調製に引続いて，鉄欠乏の恢復試 験として硫酸第一鉄経口負荷を実施した。鉄欠乏食群を 血液 Hb値によって 3 群に区分した。I 群 : Hb值 7〜8 $\mathrm{g} / \mathrm{d} l$ (平均8.1), II 群 : $9 \sim 10 \mathrm{~g} / \mathrm{d} l$ (平均9.5), 而群 : $11 \sim 12 \mathrm{~g} / \mathrm{d} l$ (平均 11.1)。対照群（IV群）はHb値13 16 $\mathrm{g} / \mathrm{d} l$ (平均15.7) であった。各群それぞれ10匹ずつとし た。これらのラットには 9 〜 10am に硫酸第一鉄 $0.3 \mathrm{mg}$ $\mathrm{Fe}$ t $0.5 \mathrm{ml}$ の脱イオン水に溶解して経口負荷した。硫酸 第一鉄の負荷は11日間に10回実施した。しかしながら第 1 回の鉄負荷時に ${ }^{59} \mathrm{FeSO}_{4}$ を約 $0.3 \mu \mathrm{ci}$ 添加した。ラッ トは約 5 日間隔で体重および血液 $\mathrm{Hb}$ 値を測定した。体

* テ 113 東京都文京区千駄木 $1-1-5 \quad * *$ テ 112 東京都文京区小石川 4-6-10 
Table 1. Composition of the iron poor diet (\%)

\begin{tabular}{lr}
\hline \hline Corn-starch & 32 \\
Granulated sugar & 30 \\
Casein & 22 \\
Soy-been oil & 5 \\
Filter paper & 5 \\
McCollum salt (No. 185, iron salt was & 4 \\
omitted) & 2 \\
Vitamin mixture*
\end{tabular}

* The vitamin mixture was purchased from Oriental Kobo (Yeast) K.K. (Tokyo).

重測定は毎回全ラットについて抗こない，Hb 判定は除 鉄飼料で飼育中は実験群対照群とも每回無作為に選んだ 20匹についてまな硫酸第一鉄経口負荷時には全ラットに ついて実施した。最終回の鉄負荷より48時間後にラット をエーテル麻酔下に採血致死させ以下の各項について測 定した。

\section{1. 血液 $\mathrm{Hb}$ 值 ${ }^{6}$}

尾静脈または心臓穿刺により採血し，シアンメトへモ グロビン法によって測定した。

\section{2. 臓器非へミン鉄の测定 ${ }^{7)}$}

肝脾の組織ホモジェネートにピロ燐酸・トリクロール 酶酸混合液を添加して加熱抽出し，0ーフェナンスロリン 法を用いて測定した。

3. 臟器非へミン鉄およひ赤血球への ${ }^{59} \mathrm{Fe}$ 取り込み

\section{の測定}

肝脾の非へミン鉄画分への取り込みはピロ燐酸・トリ クロール酶酸混合液を用いる加熱抽出液について実施し た。赤血球への取り込みはェーテル麻酔下に心臟穿刺し て得られる血液 $1.0 \mathrm{~m} l$ を $5 \mathrm{~m} l$ の等張クエン酸 $\mathrm{Na}$ 溶液の 入れてある 線測定用プラスチック小試歌管中にとり， 遠心した後に上清液を除去して測定した。放射能の測定 はウェル型 $\gamma$ 線シンチレーションカウンター（理研製） を使用した。

\section{実 験 結 果}

\section{1. 鉄欠乏食群およひ対照群の飼育期間における体重}

\section{およひ血液 Hb 值について}

1) 体重增加 60 日間の飼育によって鉄欠之食群 $(100$ 匹）の体重は $52.6 \pm 4.5 \mathrm{~g}$ より $201.2 \pm 29.3 \mathrm{~g}$, 対照群 (60匹) は $52.1 \pm 4.7 \mathrm{~g}$ より $228.4 \pm 32.0 \mathrm{~g}$ に成長した （図 1)。飼育期間の終了時の両群の体重平均値には有意 の盖がある（P<0.001）。飼料は自由摂取であり，した がってその投与量が発育の制限因子とならないので，鉄 摄取量の多少によって両群に体重の不均衡が起ったと考 えられる。

2）血液 $\mathrm{Hb}$ 值の推移 実験開始時に11.6 $\pm 1.2 \mathrm{~g} / \mathrm{d} l$ の

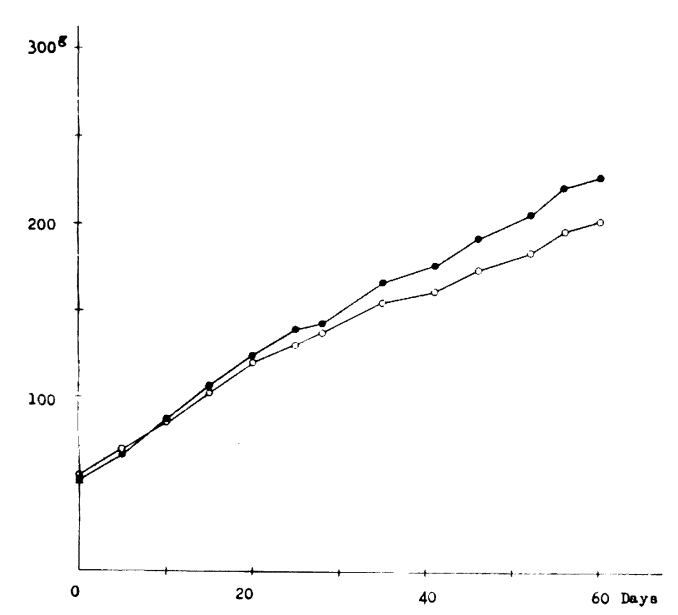

Fig. 1. Body weight of rats during the feeding of iron poor diet.

$\mathrm{O}-\mathrm{O}$ : iron poor diet administered group

: the control group

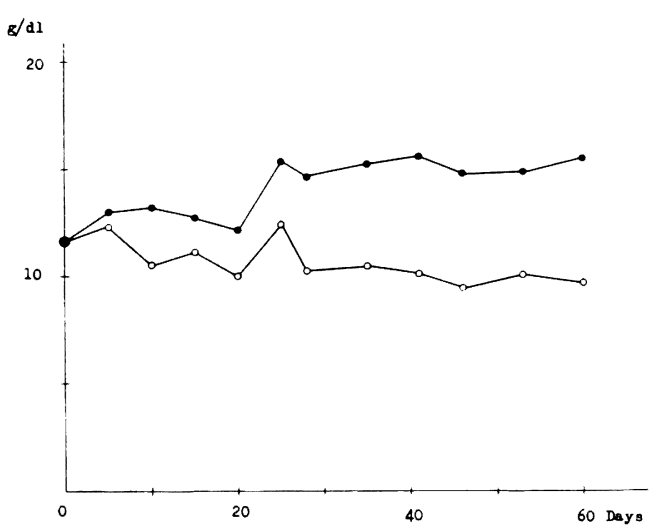

Fig. 2. Hemoglobin value of rats in response to the feeding of iron poc $r$ diet.

$\bigcirc-0$ : iron poor diet administered group

$\bullet-\bullet$ : the control group

ものが図 2 に示めす経過をたどって飼育終了時に鉄欠之 食群 $9.7 \pm 1.5 \mathrm{~g} / \mathrm{d} l$, 対照群 $15.4 \pm 1.4 \mathrm{~g} / \mathrm{d} l$ となった。両 群の $\mathrm{Hb}$ b值の間には有意の差がある $(\mathrm{P}<0.001)$ 。な打鉄 欠乏食群は飼育期間中に 2 匹死んだが，生存した98匹の ラットの血液 $\mathrm{Hb}$ 值の分布は図 3 の上5なほほ正規分布 を示めすのを認めた。

2. 硫酸第一鉄経口負荷による鉄欠乏ラットの恢復試 験

1）血液 $\mathrm{Hb}$ 值の恢復 鉄欠乏食群を $\mathrm{Hb}$ 值によって I, II, II群に分け対照群をIV群とする 4 実駼群に 0.3 $\mathrm{mg} \mathrm{Fe}$ の硫酸第一鉄を水溶液として毎日 1 回総計 10 回経 口負荷したが, その間の $\mathrm{Hb}$ 値の経過は表 2 に示めし た。終了時の $\mathrm{Hb}$ 値の增加量は I 群 $4.4 \mathrm{~g} / \mathrm{d} l$, II 群 $4.6 \mathrm{~g} /$ 


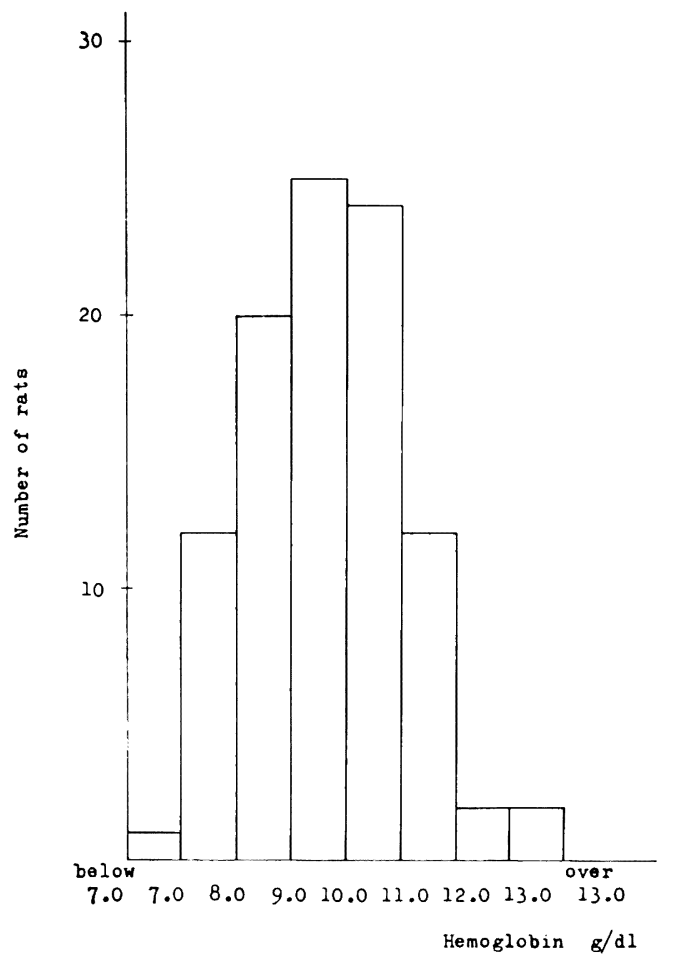

Fig. 3. Distribution of hemoglobin value of 98 rats at the end of 2 months feeding of iron poor diet.

$\mathrm{d} l$, III群 $3.5 \mathrm{~g} / \mathrm{d} l$, IV 群 $-0.9 \mathrm{~g} / \mathrm{d} l$ である。へモグロビン の恢復量は実験開始時の貧血の強さの順と一致する傾向 にある。

2) ${ }^{{ }^{9}} \mathrm{FeSO}_{4}$ の吸収率第 1 回の跌負荷は硫酸第一 鉄0.3mg Fe に痕跡量の ${ }^{59} \mathrm{FeSO}_{4}$ を添加し経口負荷し たが，その後の 9 回は非放射性の硫酸第一鉄のみを与え た。最終回の負荷より48時間後に赤血球および葴器非へ ミン鉄への ${ }^{59} \mathrm{Fe} の$ 取り込みを測定した。循環血液量を体 重の $6 \%$ とすると影, 赤球への取り込み率は I 群 43.4 \%，II群 36.3\%，III群 30.8\%であるのに対して対照群 （IV群）では 7.8\%であり, 赤血球への鉄の取り込みが 鉄欠乏食群では対照群に比べて顕著に六進している。肝 缄非へミン鉄分画への ${ }^{59} \mathrm{Fe}$ の取り込み率ては I 群 $0.7 \%$, II群 $0.8 \%$, III群 $1.6 \%$, IV群 $0.5 \%$ である。群の取り 込みが最大となり, IV群は鉄欠乏群よりやや低值をとる 傾向にある。な打脾䁍非へミン鉄への取り込みは非常に 低率であるので記载をやめた（表 3 )。

3）肝臓非へミン鉄について

（i）硫酸第一鉄経口負荷前の肝臓非へミン鉄：硫酸 第一鉄経口負荷実験と同一の分類になるよ $5 に \mathrm{Hb}$ 值で 区分して跌欠乏食群より I', II', III'群および対照群よ りIV'群を作った。肝缄非へミン鉄は新鮮重量あたりI' 群 $11.6 \mu \mathrm{g} / \mathrm{g}$, II'群 $11.6 \mu \mathrm{g} / \mathrm{g}$, III'群 $15.1 \mu \mathrm{g} / \mathrm{g}, \mathrm{IV}^{\prime}$ 群 $112.6 \mu \mathrm{g} / \mathrm{g}$ である。鉄欠乏食飼育群の肝臓非へミン鉄は 対照群の $1 / 7$ 以下であり, 鉄欠乏ラットの調製を確実に 実施できた（表 4 ）。

（ii）硫酸第一鉄経口負荷後の肝蔵非へミン鉄：肝蔵 非へミン鉄は I 群 $38.4 \mu \mathrm{g} / \mathrm{g}$, II 群 $38.7 \mu \mathrm{g} / \mathrm{g}$, III群 64.5 $\mu \mathrm{g} / \mathrm{g}, \mathrm{IV}$ 群 $126.3 \mu \mathrm{g} / \mathrm{g}$ である(表 5 )。鉄負荷前の肝葴非 ヘミン鉄の単位重量あたりの含量を表 4 の成績と見做す と，鉄負荷によるその增加量は単位重量あたりの非へミ ン鉄增加量（表 5 と表 4 の数值の差より求める）に表 5 の肝蔵重量を乗じて求められる。その結果は I 群 174.2

Table 2. Recovery of blood hemoglobin value $(\mathrm{g} / \mathrm{d} l)$ in the period of $\mathrm{FeSO}_{4}$ administration

\begin{tabular}{rcrrccc}
\hline & & \multicolumn{1}{c}{0 day } & 3rd day & 6th day & 9th day & 13th day \\
\hline \multirow{3}{*}{ Group } & I & $8.1 \pm 0.4$ & $9.0 \pm 0.5$ & $11.3 \pm 1.2$ & $13.2 \pm 1.1$ & $12.5 \pm 1.0$ \\
& II & $9.5 \pm 0.5$ & $10.7 \pm 0.5$ & $11.6 \pm 1.6$ & $13.7 \pm 1.1$ & $14.1 \pm 1.5$ \\
& III & $11.1 \pm 0.4$ & $11.4 \pm 0.8$ & $12.8 \pm 1.1$ & $14.9 \pm 1.0$ & $14.6 \pm 0.7$ \\
IV & $15.7 \pm 1.4$ & - & $14.2 \pm 1.7$ & $16.4 \pm 0.9$ & $14.8 \pm 1.2$ \\
\hline
\end{tabular}

$0.3 \mathrm{mg} \mathrm{Fe}$ was given to each rat per os divided by ten administrations. Group I, II \& III: iron deficient rats, Group IV: control rats.

Table 3. Incorporation of ${ }^{59} \mathrm{Fe}$ within red blood cells \& liver nonhemin iron 12 days after per oral administration of ${ }^{50} \mathrm{FeSO}_{4}$

\begin{tabular}{|c|c|c|c|c|}
\hline & & $\begin{array}{l}\text { Rat } \\
\text { number }\end{array}$ & $\begin{array}{l}\text { Incorporation into red blood } \\
\text { cells }\end{array}$ & $\begin{array}{l}\text { Incorporation into liver } \\
\text { nonhemin iron }\end{array}$ \\
\hline \multirow[t]{4}{*}{ Group } & I & 9 & $43.4 \pm 10.8$ & $0.7 \pm 0.3$ \\
\hline & II & 10 & $36.3 \pm 10.0$ & $0.8 \pm 0.5$ \\
\hline & III & 10 & $30.8 \pm 9.5$ & $1.6 \pm 0.9$ \\
\hline & IV & 10 & $7.8 \pm 1.0$ & $0.5 \pm 0.3$ \\
\hline
\end{tabular}

$0.3 \mathrm{mg} \mathrm{Fe}$ was administered as carrier iron. 
Table 4. Contents of liver nonhemin iron of rats before $\mathrm{FeSO}_{4}$ administration

\begin{tabular}{|c|c|c|c|c|c|c|c|}
\hline & & Rat number & $\begin{array}{c}\text { Body weight } \\
\text { g }\end{array}$ & $\begin{array}{l}\text { Hb value } \\
\qquad \mathrm{g} / \mathrm{d} l\end{array}$ & $\begin{array}{c}\text { Liver weight } \\
\mathrm{g}\end{array}$ & $\begin{array}{l}\text { Liver nonhemin } \\
\text { iron } \mu \mathrm{g} / \mathrm{g}\end{array}$ & $\begin{array}{l}\text { Total amount of } \\
\text { liver nonhemin } \\
\text { iron } \quad \mu \mathrm{g}\end{array}$ \\
\hline \multirow[t]{4}{*}{ Group } & $I^{\prime}$ & 8 & 154.9 & $8.2 \pm 0.6$ & 5.0 & 11.6 & $57.6 \pm 11.9$ \\
\hline & II' & 7 & 194.3 & $9.5 \pm 0.4$ & 5.9 & 11.6 & $66.8 \pm 14.8$ \\
\hline & III' & 6 & 210.8 & $11.1 \pm 0.6$ & 6.9 & 15.1 & $98.0 \pm 15.2$ \\
\hline & $\mathrm{IV}^{\prime}$ & 7 & 176.0 & $16.1 \pm 0.9$ & 5.5 & 112.6 & $647.7 £ 378.4$ \\
\hline
\end{tabular}

Group I', II'\& III': iron deficient rats, Group IV': control rats

Table 5. Contents of liver nonhemin iron of rats after $\mathrm{FeSO}_{4}$ administration

\begin{tabular}{lcccccc}
\hline \hline & & Rat number & $\begin{array}{c}\text { Body weight } \\
. \mathrm{g}\end{array}$ & $\begin{array}{c}\text { Liver weight } \\
\mathrm{g}\end{array}$ & $\begin{array}{c}\text { Liver nonhemin } \\
\text { iron }\end{array}$ & $\begin{array}{c}\text { Total amount of liver } \\
\text { nonhemin iron }\end{array}$ \\
\hline Group & I & 9 & 203.0 & 6.5 & 38.4 & $243.9 \pm 80.5$ \\
& II & 10 & 199.2 & 6.6 & 38.7 & $257.9 \pm 119.8$ \\
& III & 10 & 209.3 & 7.2 & 64.5 & $460.5 \pm 68.4$ \\
IV & 10 & 200.1 & 6.8 & 126.3 & $862.8 \pm 304.0$ \\
\hline \hline
\end{tabular}

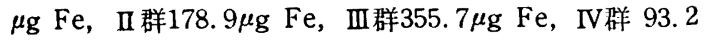
$\mu \mathrm{g} \mathrm{Fe}$ となる。 ${ }^{59} \mathrm{Fe}$ の肝臓への取り込みの場合と同様に III群の鉄萻稹が最大となり，IV群（対照）は鉄欠乏ラッ トと比べてむしろ低値をとる。

\section{考察}

鉄欠乏ラットを作るために除鉄飼料飼育法を用いた。 その飼料内鉄含量は原子吸光光度䛅で測定した結 果, $5.5 \mu \mathrm{g} / \mathrm{g}$ である。その他の鉄供給源として飲料水は脱 オン水を使用するので殆んど無視できるが，隇菌オガク ズまたは排泄䔬便を摄取する可能性もある。したがって それらに含まれる鉄量を考虑しなくてはならない。隇菌 オガクズには平均 $180 \mathrm{ppm}$ 含むが, ラットの保温, 四肢 の負傷予防または排泄物の吸着などの利点があるため使 用を継続した。ラットは飼育期間に開始時体重の約 4 倍 にまで成長し, 成長につれて招こる鉄要求の增大に対し て鉄供給を可能なかぎり抑制することによって相対的に 鉄欠乏を発症させた。以上の飼育条件によって Hb値9.7 $\pm 1.5 \mathrm{~g} / \mathrm{d} l$, および肝臓非へミン鉄は対照の $1 / 7$ 以下に低 下した鉄欠乏ラットを調製することが出来た。ラット体 重は平均値で対照群より27.2 g の低下をきたしたが，し かし外镜, 運動状態および内臟の肉眼所見には対照とく らぺて特記すべき異常を認めなかった。

${ }^{59} \mathrm{Fe}$ 経口負荷試験に扣いて ${ }^{39} \mathrm{Fe}$ 赤血球への取り込 及率を規制する因子として腸管の鉄吸収率と䑏器非へミ ン鉄量すなわちいわゆる iron pool の大きさの両因子の 関与が考えられる。しかし肝臓非へミン鉄への ${ }^{59} \mathrm{Fe}$ の取 り込み率を鉄欠乏ラットと対照ラットについて比較する と両群とす投与量の $1 \%$ 前後であり，むしろ対照群がや
や低値をとる傾向にある(表 3 )。肝臓は非へミン鉄含量 が最大の臓器であるので，この成績は非へミン鉄全体へ の取り泛みの傾向を示めすものと考えられる。したが， て赤血球への ${ }^{59} \mathrm{Fe}$ の取り込染を測定して鉄吸収染の判 定のパラメーターと認めて支障ないと思われる ${ }^{4) 99} 。$

鉄吸收率 (赤血球への取り込及率) と血液 $\mathrm{Hb}$ 值との 関係を求めるために39匹のラットについての実験成績を 四示すると図4のグラフを得られる。鉄吸収率は貧血状

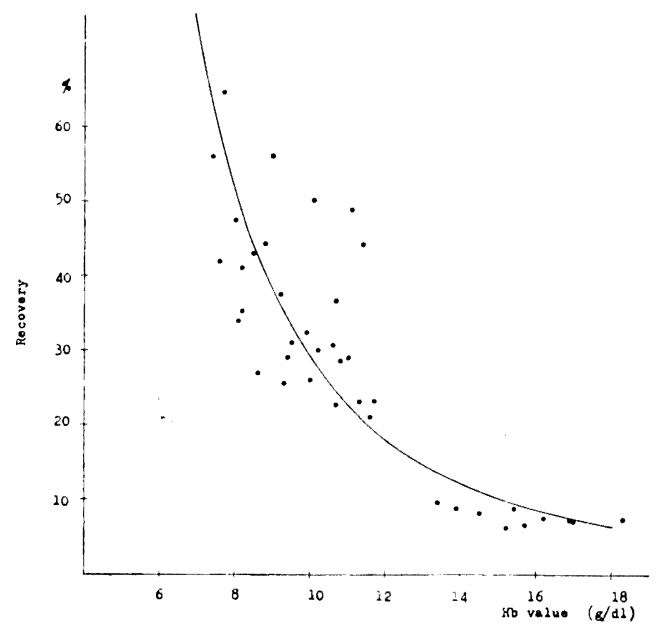

Fig. 4. The relation of hemoglobin value \& per cent recovery of ${ }^{59} \mathrm{Fe}$ in red blood cells in 39 rats.

Abscissa $(\mathrm{x})$ : hemoglobin value $(\mathrm{g} / \mathrm{d} l)$, Ordinate $(y)$ : per cent recovery of ${ }^{50} \mathrm{Fe}$ in red blood cells given by per oral administration. The equation of $y=10,895 \mathrm{x}^{-2.578}$ was calculated from this result. 


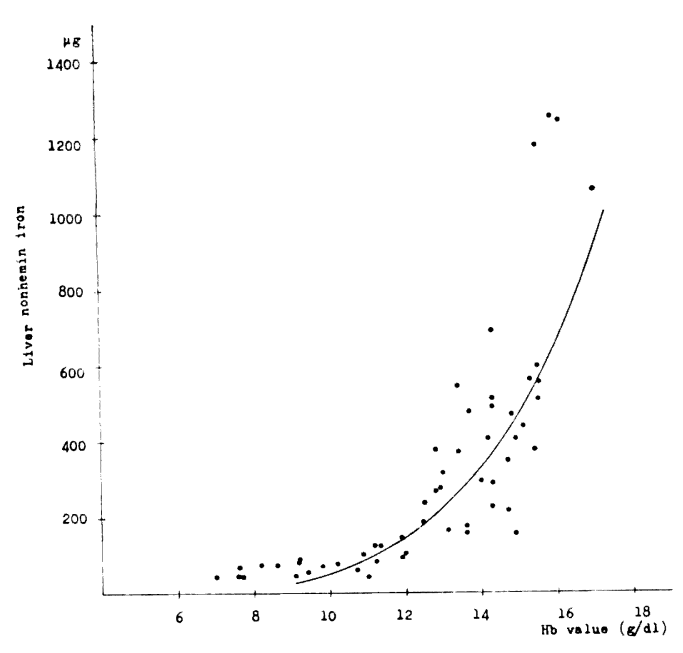

Fig. 5. The relation of hemoglobin value \& liver nonhemin iron in 55 rats.

$\operatorname{Abscissa}(\mathrm{x})$ : hemoglobin value $(\mathrm{g} / \mathrm{d} l)$ Ordinate $(\mathrm{y})$ : liver nonhemin iron $(\mu \mathrm{g} \mathrm{Fe})$ The equation of $y=2.032 \times 10^{-4} \mathrm{x}^{5.413}$ was calculated from this result.

態に沶いて函めての高值をとるが， $\mathrm{Hb}$ 値 $13 \mathrm{~g} / \mathrm{d} l$ の近傍 に拀いてほほ15\%となる。へモグロビン含量がそれ以上 の対照群においての鉄吸收率はすべて10\%以下である。 したがって両者の間に双曲線型の相関関係が成立すると 考えられるので，相関係数を Olivetti programma 101 電子部算機によって求めると $\mathrm{y}=10,895 \mathrm{x}^{-2.579}$ の実験式 を得られた。以上の実験成績によると, $\mathrm{Hb}$ 值 $13 \mathrm{~g} / \mathrm{d} l$ を 境界として盆血により光進した鉄吸収が安定化した正常 状態の鉄吸収にもどるものと考えられる。

$\mathrm{Hb}$ 值と肝臓非へミン鉄との関係を 55 匹のラットにつ いて求めると図 5 のグラフを得られる。 $\mathrm{Hb}$ 值 $13 \mathrm{~g} / \mathrm{d} l$ の 近傍を境界としてそれ以上に括いては肝缄非へミン鉄の 急激な增大を認める。すなわちラットは銠欠乏貧血にお いて鉄吸収摔が克進し同時に吸収された鉄の大部分は， $\mathrm{Hb}$ 合成に利用されるか， $\mathrm{Hb}$ 值 $13 \mathrm{~g} / \mathrm{d} l$ 以上となると鉄吸 収染が低下した安定状態になると同時に摄取された鉄は むしろ非へミン鉄へ優先的に取り込まれると考えられ る。この成績は正の曲線相関が成立すると推定されるの で, $\mathrm{Hb}$ 值 $10 \mathrm{~g} / \mathrm{d} l$ 以上の測定值 44 例について $\mathrm{Hb}$ 值と肝蔵 非へミン鉄の間の相関係数を前記と同栐に求めると, $\mathrm{y}=$ $2.032 \times 10^{-4} \mathrm{x}^{5.413}$ の実験式が得られた。このよ5に鉄吸 収は生体の需要度に応じて円滑に実施されるのでこの 調節を支配する調節機構の存在を想像させる可能性が強 いと考えられる。Greenberger らは腸管の鉄吸収の効率
に影響を及は寸体液性因子の存在を報告しているが ${ }^{10)}$ ， 機構の本態または調節作用を活動させる誘因についての 研究など今後に残された興味ある課題であると考えられ る。

\section{結論}

1）ドンリューラット（雄）平均体重 $52 \mathrm{~g} / 60$ 匹を 2 分し，除鉄飼料飼育 $(100$ 匹) および対照飼育 (60匹) をそれぞれ 2 力月間実施した。その結果鉄欠乏食群では 血液 $\mathrm{Hb}$ 值 $9.7 \pm 1.5 \mathrm{~g} / \mathrm{d} l$, 肝蔵非へミン鉄 $11.6 \sim 15.1 \mu \mathrm{g} /$

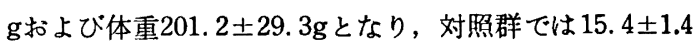
$\mathrm{g} / \mathrm{d} l, 112.6 \mu \mathrm{g} / \mathrm{g}$ よび $228.4 \pm 32.0 \mathrm{~g}$ (同順序) となっ た。

2）鉄欠乏食群および対照群に0.3mg Fe の硫酸第一 鉄を連続10回経口負何した後の鉄吸収率, 血液 $\mathrm{Hb}$ 值お よび肝䁍非へミン鉄について測定した。第 1 回の鉄投与 に添加した ${ }^{59} \mathrm{FeSO}_{4}$ の吸収率は鉄欠乏食群では $30.8 \%$ 以上，対照群では $7.8 \%$ である。鉄負荷の結果鉄欠乏食 群では血液 $\mathrm{Hb}$ 值扣よび肝臓非へミン鉄の恢復をみとめ たが，対照群の $\mathrm{Hb}$ 值には殆んど変化が無かった。

3）血液 $\mathrm{Hb}$ 值と鉄吸収率の間には負の曲線相関，ま た血液 $\mathrm{Hb}$ 值と肝蔵非へミン鉄の間には正の曲線相関を 認められ何れも実験式を計算した。

この研究にあたってご援助を賜わった島田敏夫教授に 厚く謝意を表します。

\section{文献}

1) Manis, J. G., Schacter, D.: Am. J. Physiol., 203, 81 (1962)

2) Helbock, H. J., Saltman, P.: Biochim. Biophys. Acta, 135, 979 (1967)

3) Wheby, M. S., Jcnes, L. G., Crosby, W.H.: J. Clin. Invest., 43, 1433 (1964)

4) Hoek, R.V., Conrad Jr., M.E.: J. Clin. Invest., 40. 1153 (1961)

5) Wiseman, G. : Absorption From The Intestine, 246 (1964), Academic Press, New York

6) Wintrobe, M. M.: Clinical Hemotology, 396 (1962), Lea \& Febiger, Philadelphia

7）吉野芳夫：日医大誌，19，395（1952）

8）吉野劳夫, 熊木敏郎, 山下博邦, 若林恒郎 : 日医 大誌, 30, 19 (1964)

9) Fried, W., Plzak, L. F., Jacobson, L. O., Goldwasser, E.: Proc. Soc. Exp. Biol. Med., 94. 237 (1957)

10) MacDermott, R. P., Greenberger, N. J.:Clin. Res., 17, 306 (1969)

（昭和 46 年 2 月 4 日受理） 